in the country outside Toowoomba. She made trips to India, to the Adelaide Arts Festival and one last visit to England before her deteriorating health made further travel impossible.

Joan had been married for over 25 years to Bill Oliphant. They had travelled the world together and he had been her partner in all her ventures over the years. She is survived by Bill and their daughter, Sarah, and son, Guy. Sadly, she did not live to see the birth of her first grandchild.

She was a Foundation Member of the Royal College of Psychiatrists and became a Fellow of the Royal Australian and New Zealand College of Psychiatrists after moving to Australia. She was elected FRCPsych a couple of years before her death.

The Ridley Unit, a medium secure unit at Baillie Henderson Hospital was named in her honour.

JEFFERY THOMPSON

Irving Shribman, Consultant in Forensic Psychiatry, Home Office

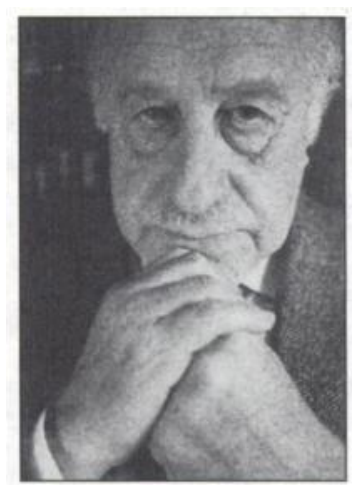

"I find it hard to believe that someone so interesting and so vital is no longer with us - truly the end of an era, when psychiatry was more of an art and less of a business than it is now", a colleague wrote on learning of Irving's death. He had not got the better of a coronary which last year chastised him after 75 years of living life to the full.

In 1944 , as a (neutral) Irish national, he volunteered for the RAMC. An Acting Major with the $B A O R$, he treated military wounded on both sides in general surgery and graded psychiatric postings. His commanding officer said of him, "he is one of the most likeable of men. Quiet, yet possessing a great sense of humour, he was universally popular with his medical colleagues and patients". And still wearing $a{ }^{\prime} \mathrm{J} *$ on his identify disc, he helped as some of the Nazi concentration camps were opened to the horrified world.

These strengths were carried into civilian work. As a consultant psychiatrist since 1953, his influence and inspiration throughout the NHS in Buckinghamshire has been unquestioned. In medical and senior managerial roles, and later in forensic psychiatry, he maintained a stature and versatility, a belligerence and cynicism - and always, a touch of class. These qualities will be sorely missed by all those who knew him, and by those that loved him. He is survived by a large family and by Hazel, his wife of 43 years.

\section{Career summary}

Irving Shribman, consultant psychiatrist, NHS, 1953-1981; consultant in forensic psychiatry, Home Office, 1981-1994. Born, Limerick, 1 June 1917, died 10 February 1994. Educated at Haberdasher Askes and Trinity College Dublin (MA; MB; BCh; BAO 1942). Royal Army Medical Corps, Acting Major, 1944-45. Appointments to Maudsley, Banstead and Napsbury Mental Hospitals unit 1953. Consultant Psychiatrist at St Johns, Stoke Mandeville, Amersham and High Wycombe Hospitals, Buckinghamshire (1953-1981). JP 1974; General Commissioner of Taxes 1981. Home Office appointments to Huntercombe Borstal; Grendon Underwood Open Prison; Aylesbury Prison; Broadmoor Hospital (Medical Advisory Committee). JONATHAN SHRIBMAN

*'J' denoted Jew as a religious denomination 